\title{
Dynamic NanoSIMS ion imaging of unicellular freshwater algae exposed to copper
}

\author{
Vera I. Slaveykova • Cédric Guignard • Tanja Eybe • \\ Henri-Noël Migeon • Lucien Hoffmann
}

Received: 5 September 2008 /Revised: 10 October 2008 /Accepted: 15 October 2008 / Published online: 5 November 2008

(C) Springer-Verlag 2008

\begin{abstract}
This work demonstrates the capabilities of nanoscale secondary-ion mass spectrometry, using the Cameca NanoSIMS50 ion microprobe, to detect and image the copper-ion distribution in microalgal cells exposed to nanomolar and micromolar copper concentrations. In parallel to ${ }^{63} \mathrm{Cu}^{-}$secondary-ion maps, images of ${ }^{12} \mathrm{C}^{-}$, ${ }^{12} \mathrm{C}^{14} \mathrm{~N}^{-}$, and ${ }^{31} \mathrm{P}^{-}$secondary ions were collected and analysed. A correlation of ${ }^{63} \mathrm{Cu}^{-}$secondary-ion maps with those found for ${ }^{12} \mathrm{C}^{14} \mathrm{~N}^{-}$and ${ }^{31} \mathrm{P}^{-}$demonstrated the possible association of $\mathrm{Cu}$ with cell components rich in proteins and phosphorus. The results highlighted the potential of NanoSIMS for intracellular tracking of essential trace elements such as $\mathrm{Cu}$ in single cells of the microalga Chlorella kesslerii.
\end{abstract}

Keywords NanoSIMS · Microalgae · Ion mapping · Copper ion images

\footnotetext{
V. I. Slaveykova $(\bowtie)$

Environmental Biophysical Chemistry,

Environmental Science and Technology Institute,

School of Architecture, Civil and Environmental Engineering,

Ecole Polytechnique Fédérale de Lausanne (EPFL),

Station 2, 1015 Lausanne, Switzerland

e-mail: vera.slaveykova@epfl.ch

C. Guignard · T. Eybe $\cdot$ L. Hoffmann

Department of Environment and Agro-Biotechnologies (EVA),

Public Research Center-Gabriel Lippmann,

41 rue du Brill, 4422 Belvaux, Luxembourg

H.-N. Migeon

Department of Science and Analysis of Materials (SAM),

Public Research Center-Gabriel Lippmann,

41 rue du Brill, 4422 Belvaux, Luxembourg
}

\author{
Abbreviations \\ LA-ICP-MS Laser ablation inductively coupled plasma \\ mass spectrometry \\ PIXE Particle-induced X-ray emission \\ SIMS Secondary-ion mass spectrometry \\ XAS X-ray absorption spectroscopy \\ XRF X-ray fluorescence
}

\section{Introduction}

Effect-oriented environmental analysis is emerging as an important component in hazard identification of environmental contaminants [1]. Among the different groups of environmental contaminants [2], metals such as copper have a particular position. At trace concentrations, copper is an essential micronutrient for most living organisms, because it participates in electron transport and in many biologically important reactions. However, copper can become highly cytotoxic, e.g. causing oxidative damage and interfering with important cellular events [3], if accumulated in excess of cellular needs. Because the biological effects (e.g. toxicity) are a complex function of the contaminants' cellular concentrations, intracellular distribution, and speciation, new analytical tools and strategies able to provide information at cellular and subcellular levels are required. The most common analytical strategy for understanding a metal's role from a sub-cellular perspective involves separation and detection of individual organelles and/or utilization of different organelle-specific labelling probes (reviewed by Olson et al. [4]). Alternatively, complementary and relevant biological metal information can be obtained by different recent developments in analytical techniques, including PIXE, $\mu$-XAS, XRF, SIMS, LA-ICP-MS, and a number of hyphenated techniques. This 
allows for qualitative and quantitative imaging of the distribution, and determination of intracellular speciation, as reviewed in Ref. [5]. Among these techniques, dynamic secondary-ion mass spectrometry (SIMS) [6] and, in particular, nanoscale (Nano) SIMS, is emerging as a powerful tool for the determination of ion distributions and the dynamics of different processes, using trace element analysis both of natural and isotopically enriched elements, for example $\mathrm{C}, \mathrm{N}, \mathrm{O}, \mathrm{Mg}, \mathrm{Si}, \mathrm{S}$, and I, in single cells, with a high resolution (e.g. $50 \mathrm{~nm}$ ) and a high sensitivity. NanoSIMS has been successfully applied in the biological and biomedical sciences [7-10] and in environment-related disciplines such as geology [11], geochemistry [12], and cosmochemistry [13]. Very recently, the potential of NanoSIMS in soil biogeochemistry and ecology has also been explored [14-16].

The objective of this study was to determine the intracellular distribution of $\mathrm{Cu}$ in single cells of unicellular microalgae, compared with that of the major structural elements $\mathrm{C}, \mathrm{N}$, and $\mathrm{P}$. For this purpose, the unique capabilities of NanoSIMS 50 were used to directly visualise these elements at the cellular level and to follow their occurrence along the cell axes. The green microalga Chlorella kesslerii was chosen because it represents the primary producers playing an important role in aquatic systems, and the base of the aquatic food chain.

\section{Experimental}

Exposure of algae to $\mathrm{Cu}$ and intracellular $\mathrm{Cu}$ determination

C. kesslerii was cultured in an OECD algal growth medium [17] at $20^{\circ} \mathrm{C}$, with rotary shaking (100 rpm) and a $12: 12$ hour light-dark regime. Cells were collected by gentle filtration when the mid-exponential algal growth phase was attained, and washed with metal-free experimental medium. Algae were further re-suspended in experimental medium containing $1 \mathrm{nmol} \mathrm{L}^{-1}$ or $10 \mu \mathrm{mol} \mathrm{L}^{-1} \mathrm{Cu}\left(\mathrm{NO}_{3}\right)_{2}$ in $10 \mathrm{mmol}$ $\mathrm{L}^{-1}$ MES (2-[N-morpholino]ethanesulfonic acid; Fluka, p.a.) at $\mathrm{pH} 6.0$ to a cell density of approximately $10^{5}$ cells $\mathrm{mL}^{-1}$. After $8 \mathrm{~h}$ exposure, $50-\mathrm{mL}$ aliquots of algal suspensions were filtered through $3.0-\mu \mathrm{m}$ pore-size regenerated cellulose filters. Algae on the filter were then washed twice with $5 \mathrm{~mL}$ $10 \mathrm{mmol} \mathrm{L}^{-1}$ EDTA (ethylenediaminetetraacetic acid; Fluka, p.a.) to remove $\mathrm{Cu}$ adsorbed on the cell by using a previously optimized methodology [18], then re-suspended in $20 \mathrm{~mL}$ copper-free experimental medium and divided into two portions. The first was used to prepare and fix samples for NanoSIMS measurements, as described in the next section. The second was centrifuged for $10 \mathrm{~min}$ at $100 \mathrm{~g}$. The amount of intracellular $\mathrm{Cu}$ was measured in the algal pellet following digestion with $500 \mu \mathrm{L}$ conc. $\mathrm{HNO}_{3}$ (Suprapur, Baker) at
$100{ }^{\circ} \mathrm{C}$ for $1 \mathrm{~h}$. The $\mathrm{Cu}$ concentration in the intracellular fractions was measured by inductively coupled plasma mass spectrometry (ICP-MS) (Hewlett-Packard 4500; Agilent Technologies, Palo Alto, CA, USA). Controls and corrections of the blanks and chemicals used were performed. Cell numbers and densities were determined with a Coulter Multisizer III particle counter (50- $\mu \mathrm{m}$ orifice). The average cell diameter was 3.6-3.8 $\mu \mathrm{m}$.

\section{Sample preparation for NanoSIMS}

All the chemicals used for sample preparation were ordered from Sigma-Aldrich (Seelze, Germany). Algal cells were harvested by centrifugation (Sanyo/MSE Harrier 18/80 Refrigerated; Jepson Bolton, Watford, UK) for $1-2 \mathrm{~min}$ at $100 \mathrm{~g}$ at room temperature, and then washed with $10 \mathrm{mmol} \mathrm{L}^{-1}$ MES. The cells were fixed in $1 \%$ agar cubes (edge length $1-2 \mathrm{~mm}$ ) prior to the embedding procedure. This method allowed the resin embedding of cells without further centrifugation.

The first fixation was done with 5\% glutaraldehyde in $10 \mathrm{mmol} \mathrm{L}^{-1}$ MES overnight. Cells were washed in $10 \mathrm{mmol} \mathrm{L}^{-1} \mathrm{MES}$ and then post-fixed with osmium tetroxide $\left(0.2 \%\right.$ in $\left.\mathrm{H}_{2} \mathrm{O}\right)$ for $16 \mathrm{~h}$. After washing with MES and dehydration with five increasing acetone concentrations $(30,50,70,90$, and $100 \%$ acetone), the algal cells were embedded in epoxy resin (Epon 812 substitute). The samples were cut to $500-\mathrm{nm}$ semi-thin sections with an ultramicrotome (Leica Ultracut, Le Pecq Cedex, France) equipped with a diamond knife and deposited on silicon wafers (Siltronix, Archamps, France) for NanoSIMS analysis. Before analysis the samples were stored in plastic boxes at room temperature in the dark.

NanoSIMS imaging of Chlorella kesslerii individual cells

NanoSIMS imaging was carried out on the Cameca NanoSIMS 50 ion microprobe (Cameca, Courbevoie, France). $\mathrm{Cs}^{+}$primary ions were generated by a caesium source and accelerated towards the sample surface as a tightly focused ion beam with a probe working diameter of approximately $50 \mathrm{~nm}$, an intensity of $0.8 \mathrm{pA}$, and an ion-impact energy of $16 \mathrm{keV}$. The secondary beam was focused and guided through several transfer lenses to the entrance of the mass spectrometer, which was a double-focusing filter analyzer. The first filter was an electrostatic sector and the second filter was a magnetic sector in which a variable magnetic field, perpendicular to secondary ion motion, deflects ions according to their momentum. According to the mass-tocharge $(\mathrm{m} / \mathrm{z})$ ratio, ions were discriminated by their differential deviation in the magnetic field to a parallel multidetector system. Up to five masses can be simultaneous detected and counted. In this study, signals arising 
from secondary ions of ${ }^{12} \mathrm{C}^{-},{ }^{12} \mathrm{C}^{14} \mathrm{~N}^{-},{ }^{31} \mathrm{P}^{-},{ }^{63} \mathrm{Cu}^{-}$, and ${ }^{65} \mathrm{Cu}^{-}$were acquired simultaneously. As a mass resolution of 1800 is necessary to distinguish ${ }^{63} \mathrm{Cu}^{-}$and ${ }^{31} \mathrm{P}^{16} \mathrm{O}_{2}{ }^{-}$ ions, the mass spectrometer was set to a minimum resolution of 3500 . All images were acquired in $256 \times 256$ pixels format with a counting time of $20 \mathrm{~ms}$ per pixel.

\section{Results and discussion}

The sub-cellular distribution of copper in individual cells of the alga $C$. kesslerii was mapped by measurement of ${ }^{63} \mathrm{Cu}^{-}$ and ${ }^{65} \mathrm{Cu}^{-}$secondary ions in cells exposed to $1 \mathrm{nmol} \mathrm{L}^{-1}$ or
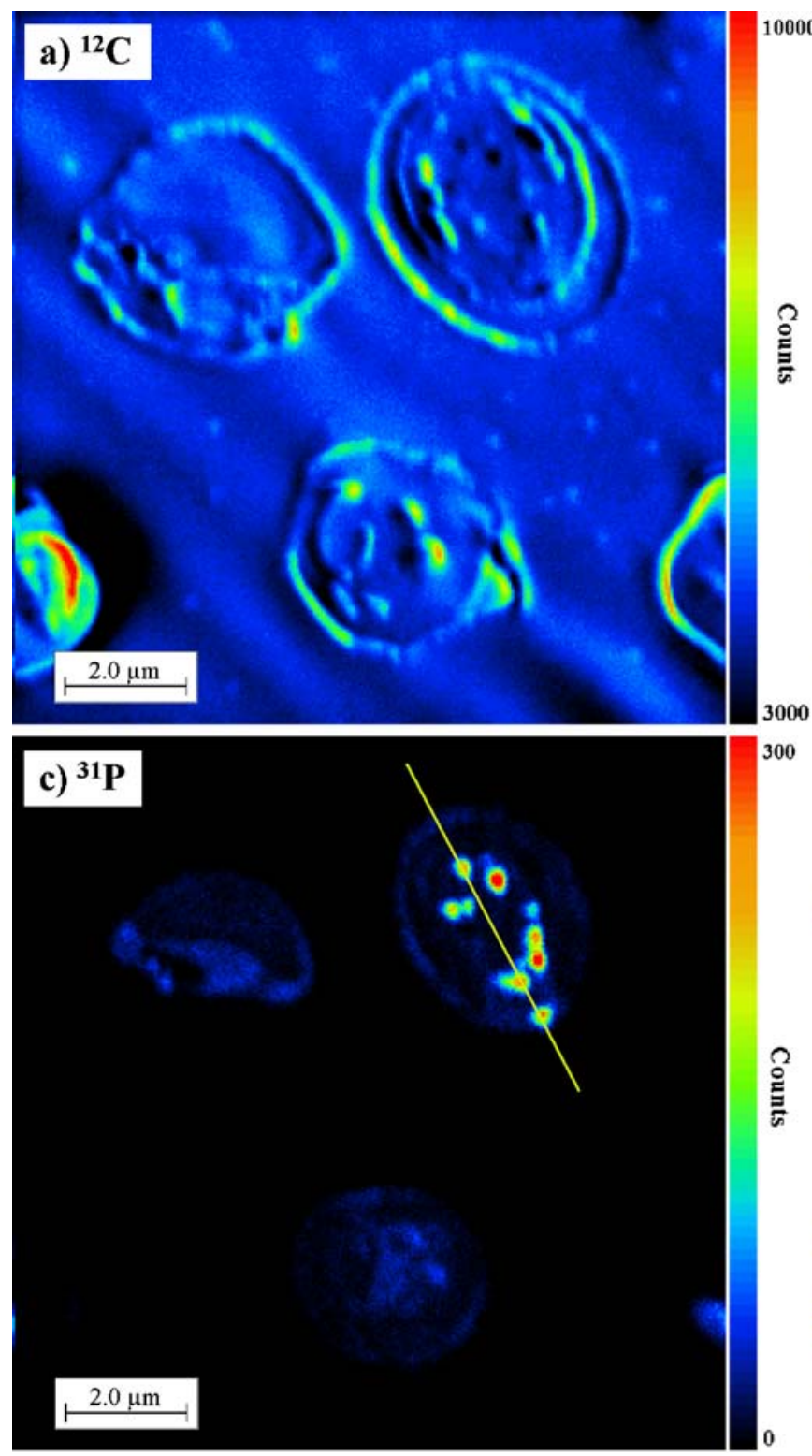

Fig. $1{ }^{12} \mathrm{C}^{-},{ }^{12} \mathrm{C}^{14} \mathrm{~N}^{-},{ }^{31} \mathrm{P}^{-}$, and ${ }^{63} \mathrm{Cu}^{-}$secondary ion distributions in the whole cell of Chlorella kesslerii. Different colours correspond to different intensities of the signal, which increase from black to red.
$10 \mu \mathrm{mol} \mathrm{L} \mathrm{L}^{-1}$ copper, representative of natural and heavily contaminated waters. In order to provide cell background images, ion mapping of the main elements that occur in biological tissues, ${ }^{12} \mathrm{C}^{-},{ }^{12} \mathrm{C}^{14} \mathrm{~N}^{-}$, and ${ }^{31} \mathrm{P}^{-}$secondary ions was performed in parallel. The existing correlation between secondary ion images of ${ }^{12} \mathrm{C}^{-},{ }^{12} \mathrm{C}^{14} \mathrm{~N}^{-}$, and ${ }^{31} \mathrm{P}^{-}$and the knowledge of the composition of the main cellular components were used to interpret the results obtained. For example, a combination of a high ${ }^{12} \mathrm{C}^{-}$signal with lower ${ }^{12} \mathrm{C}^{14} \mathrm{~N}^{-}$(Fig. 1a,b) in the periphery of the cell (e.g. cell wall), may indicate lipid or/and sugar contents [8], which is consistent with the cellulose-rich walls of Chlorella cells. High ${ }^{12} \mathrm{C}^{14} \mathrm{~N}^{-}$may indicate proteins or
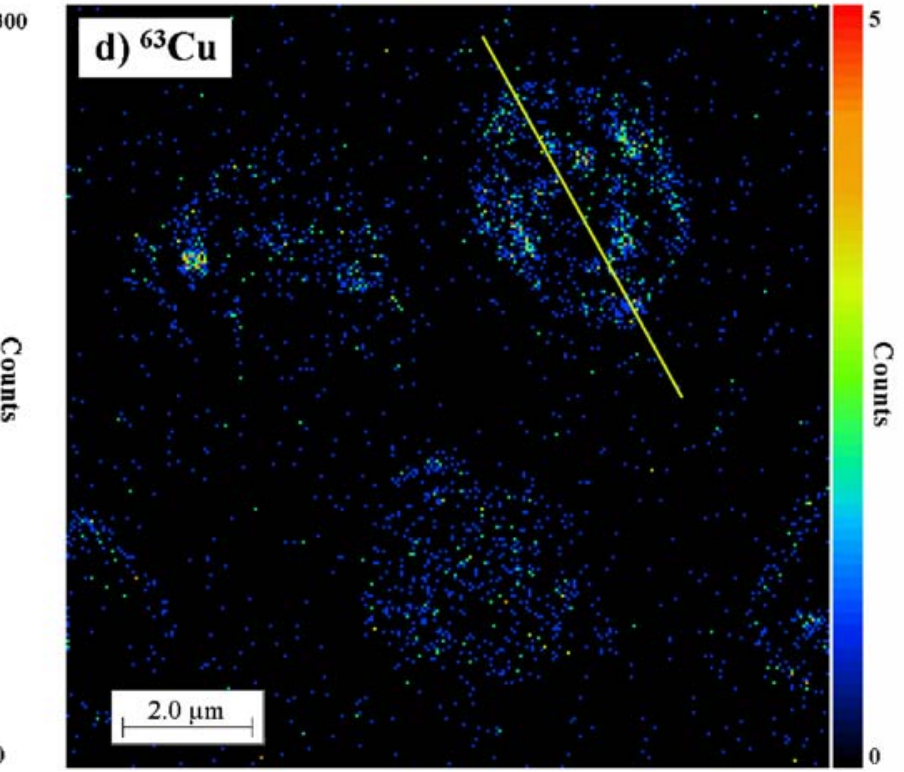

The straight lines represent the line scans made in the region of interest, given in Fig. 2 
glycoproteins, and ${ }^{12} \mathrm{C}^{-}$associated with ${ }^{31} \mathrm{P}^{-}$indicates phospholipids. Higher ${ }^{31} \mathrm{P}^{-}$(Fig. 1c, red spots) associated with lower ${ }^{12} \mathrm{C}^{14} \mathrm{~N}^{-}$(Fig. 1b, blue spots) probably corresponds to phosphate granules [8]. In several regions of interest the line scans for the elements ${ }^{63} \mathrm{Cu}^{-},{ }^{12} \mathrm{C}^{14} \mathrm{~N}^{-}$, and ${ }^{31} \mathrm{P}^{-}$were accomplished to explore the possible association of $\mathrm{Cu}$ with other sub-cellular components.

$\mathrm{Cu}$ ion mapping in the cells of Chlorella kesslerii exposed to $1 \mathrm{nmol} \mathrm{L}{ }^{-1} \mathrm{Cu}$

A good signal was obtained for the ${ }^{63} \mathrm{Cu}^{-}$secondary ion in the algae exposed to $1 \mathrm{nmol} \mathrm{L}{ }^{-1} \mathrm{Cu}$, whereas the signal for ${ }^{65} \mathrm{Cu}^{-}$secondary ions was near the detection limits of the technique, because of the lower natural abundance $(30.83 \%)$. The ${ }^{63} \mathrm{Cu}^{-}$secondary-ion map obtained from individual cells of the alga Chlorella kesslerii is presented in Fig. 1d, and corresponds to an average cellular $\mathrm{Cu}$ concentration of $5 \times 10^{5} \mathrm{Cu}$ atoms per cell, determined by measurements with ICP-MS. A very weak ${ }^{63} \mathrm{Cu}^{-}$signal was detected at the cell periphery, indicating that the quantity of $\mathrm{Cu}$ in the cell wall and membrane is negligible compared with that in the cell interior. The above observations are in agreement with $\mathrm{Cu}$ biouptake experiments, that revealed the tendency of $\mathrm{Cu}$ to enter the cell, rather than to be adsorbed by the cell surface [19], and confirmed the efficiency of $\mathrm{Cu}$ extraction from the cell wall by $10 \mathrm{mmol} \mathrm{L}^{-1}$ EDTA [18], used to distinguish between intracellular and adsorbed metal on the algal surface.

Furthermore, ${ }^{63} \mathrm{Cu}^{-}$sub-cellular distribution matched phosphorus and protein distributions. Higher ${ }^{63} \mathrm{Cu}^{-}$signal (Fig. 1d) corresponds to higher ${ }^{31} \mathrm{P}^{-}$(Fig. 1c, red spots) and lower ${ }^{12} \mathrm{C}^{14} \mathrm{~N}^{-}$(Fig. 1b, blue spots). These observations demonstrate that $\mathrm{Cu}$ probably associates with the phosphate granules in the cell [8]. On the other hand, the high signal of ${ }^{63} \mathrm{Cu}^{-}$followed the high ${ }^{12} \mathrm{C}^{14} \mathrm{~N}^{-}$and high ${ }^{31} \mathrm{P}^{-}$intensity, which may point to $\mathrm{Cu}$ association with the nucleus.

The above considerations were further confirmed by a line scan of the intensity of the signals of ${ }^{63} \mathrm{Cu}^{-},{ }^{12} \mathrm{C}^{14} \mathrm{~N}^{-}$, and ${ }^{31} \mathrm{P}^{-}$demonstrated in Fig. 2. The intensity profiles of ${ }^{63} \mathrm{Cu}^{-}$closely followed those of ${ }^{31} \mathrm{P}^{-}$. On the other hand the large ${ }^{12} \mathrm{C}^{14} \mathrm{~N}^{-}$over the whole cell overlaps both the ${ }^{63} \mathrm{Cu}^{-}$ and ${ }^{31} \mathrm{P}^{-}$profiles, making precise interpretation of the images difficult. In addition, ${ }^{63} \mathrm{Cu}^{-}$accumulation followed spots rich in ${ }^{12} \mathrm{C}^{14} \mathrm{~N}^{-}$(Fig. 1b) and poor in ${ }^{31} \mathrm{P}^{-}$(Fig. 1c), which further suggests that, in addition to the polyphosphate granules, $\mathrm{Cu}$ may be associated with the protein-rich cell organelles and the nucleus.

$\mathrm{Cu}$ ion mapping in the algal cells exposed to $10 \mu \mathrm{mol} \mathrm{L}{ }^{-1} \mathrm{Cu}$

Ion images collected in algal cells exposed to $10 \mu \mathrm{mol} \mathrm{L} \mathrm{L}^{-1}$ $\mathrm{Cu}$ (Fig. 3) showed that algal cells were intact following

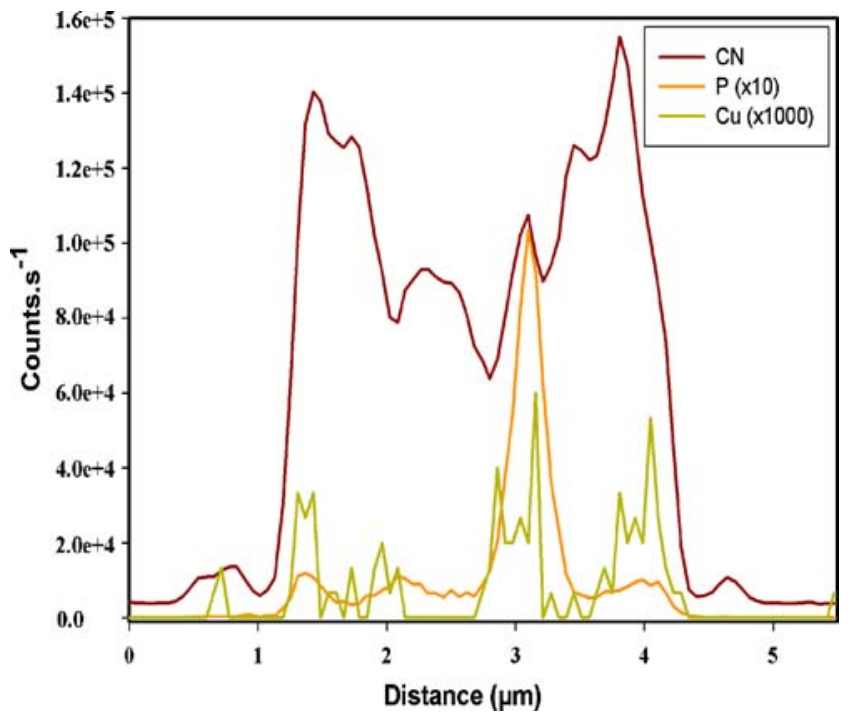

Fig. 2 Line-scan data collected across the alga in the region of interest as depicted in Fig. 1

exposure to toxic copper concentrations for $8 \mathrm{~h}$. Both ${ }^{63} \mathrm{Cu}^{-}$ and ${ }^{65} \mathrm{Cu}^{-}$isotopes were visualized in the cytosolic space. The secondary-ion maps obtained correspond to cellular $\mathrm{Cu}$ concentrations of $(1.5 \pm 0.5) \times 10^{9}$ atoms per cell exposed to $10 \mu \mathrm{mol} \mathrm{L}{ }^{-1} \mathrm{Cu}$. The ${ }^{63} \mathrm{Cu}^{-}$ion signal near the cell periphery (e.g. cell wall) was lower than that in the cell interior, demonstrating that the EDTA extraction procedure was rather efficient even after exposure to a high $\mathrm{Cu}$ concentration. Similarly to images obtained for algae exposed to $1 \mathrm{nmol} \mathrm{L}^{-1} \mathrm{Cu}^{2+}$, both ${ }^{63} \mathrm{Cu}^{-}$and ${ }^{65} \mathrm{Cu}^{-}$subcellular distributions generally followed ion maps obtained for ${ }^{12} \mathrm{C}^{14} \mathrm{~N}^{-}$and ${ }^{31} \mathrm{P}^{-}$. Interestingly the high ${ }^{63} \mathrm{Cu}^{-}$signal (Fig. 3d) corresponded to the higher ${ }^{31} \mathrm{P}^{-}$and lower ${ }^{12} \mathrm{C}^{14} \mathrm{~N}^{-}$ (Fig. 4a) in the central part of the cell, indicating a possible association with phosphate granules, which are known to sequester and store copper [8, 21, 22].

On the one hand, high ${ }^{63} \mathrm{Cu}^{-}$values are obtained in regions yielding strong ${ }^{12} \mathrm{C}^{14} \mathrm{~N}^{-}$and ${ }^{31} \mathrm{P}^{-}$signals, most likely corresponding to cell nucleotides. This might suggest that at high exposure concentrations, $\mathrm{Cu}$ can affect the cell nucleus. On the other hand, it can also be noticed that $\mathrm{Cu}$ can be found in zones with lower ${ }^{31} \mathrm{P}^{-}$, which may indicate an association of $\mathrm{Cu}$ with different proteins.

Overall, these preliminary measurements demonstrated that NanoSIMS is a very promising tool for mapping subcellular ion distribution of elements such as $\mathrm{Cu}$ in single cells, simultaneously to those of main cellular elements N, C, and P. To our knowledge, this is the first report showing the applicability of NanoSIMS analysis to study of $\mathrm{Cu}$ distribution in microalgal species exposed to trace $\left(\mathrm{nmol} \mathrm{L}^{-1}\right)$ and

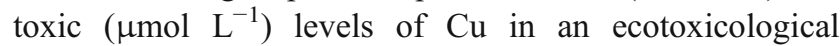
context. The unique features of the NanoSIMS technique, combining high element specificity, high sensitivity, and 

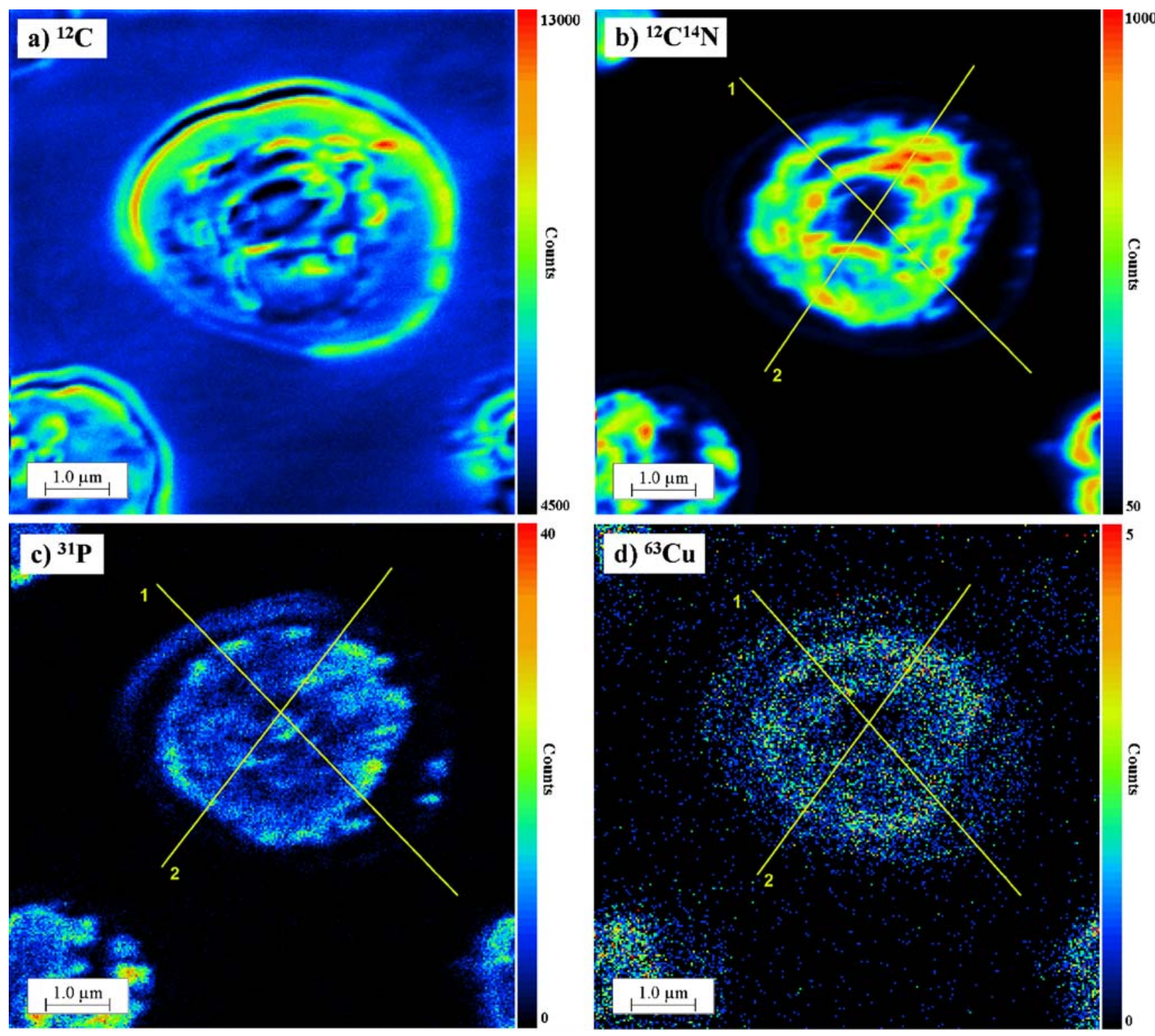

Fig. $3{ }^{12} \mathrm{C}^{-},{ }^{12} \mathrm{C}^{14} \mathrm{~N}^{-},{ }^{31} \mathrm{P}^{-}$, and ${ }^{63} \mathrm{Cu}^{-}$distributions in cells of Chlorella kesslerii exposed to $10 \mu \mathrm{mol} \mathrm{L} \mathrm{L}^{-1} \mathrm{Cu}(\mathrm{II})$. The straight lines represent the line scans made in the two regions of interest, given in

nanometre spatial resolution, have opened up new fields for tracking trace elements in unicellular microorganisms such as green algae, which represent the base of the food chain in aquatic ecosystems. In addition, the simultaneous ion imaging of two copper isotopes makes study of the dynamics of different cellular processes involving $\mathrm{Cu}$ possible, e.g. by using samples enriched with ${ }^{65} \mathrm{Cu}^{-}$.

Although providing a background cell image, the applied technique is not able to provide the sub-cellular compartment distribution, because the different organelle membranes have almost the same composition of the structural elements $(\mathrm{C}, \mathrm{N}, \mathrm{O}, \mathrm{P}$, and $\mathrm{S})$ and lack contrast in ion images [20]. Hence, it is currently not possible to reveal with certainty the various cellular organelles using NanoSIMS

Fig. 4 Different colours correspond to the different intensities of the signal, which increase from black to red

imaging. This makes it difficult to compare the ion images obtained in this study with literature data available on the ultrastructural localization of $\mathrm{Cu}$ in algae, because NanoSIMS provides only indirect information about algal cell morphology. Furthermore, it is worth noting that the chemical fixation procedure used in this work might involve a risk of ion redistribution before cell embedding, even if the ion mobility is considerably reduced by use of glutaraldehyde and osmium tetroxide. Thus, alternative sample-preparation procedures could be envisaged to improve the fixation of cell tissues, particularly if highly diffusible ions (i.e. $\mathrm{K}, \mathrm{Na}, \mathrm{Mg}$, and $\mathrm{Ca}$ ) have to be monitored. To that purpose, cryo-fixation techniques have recently been developed and are now regarded as the best 

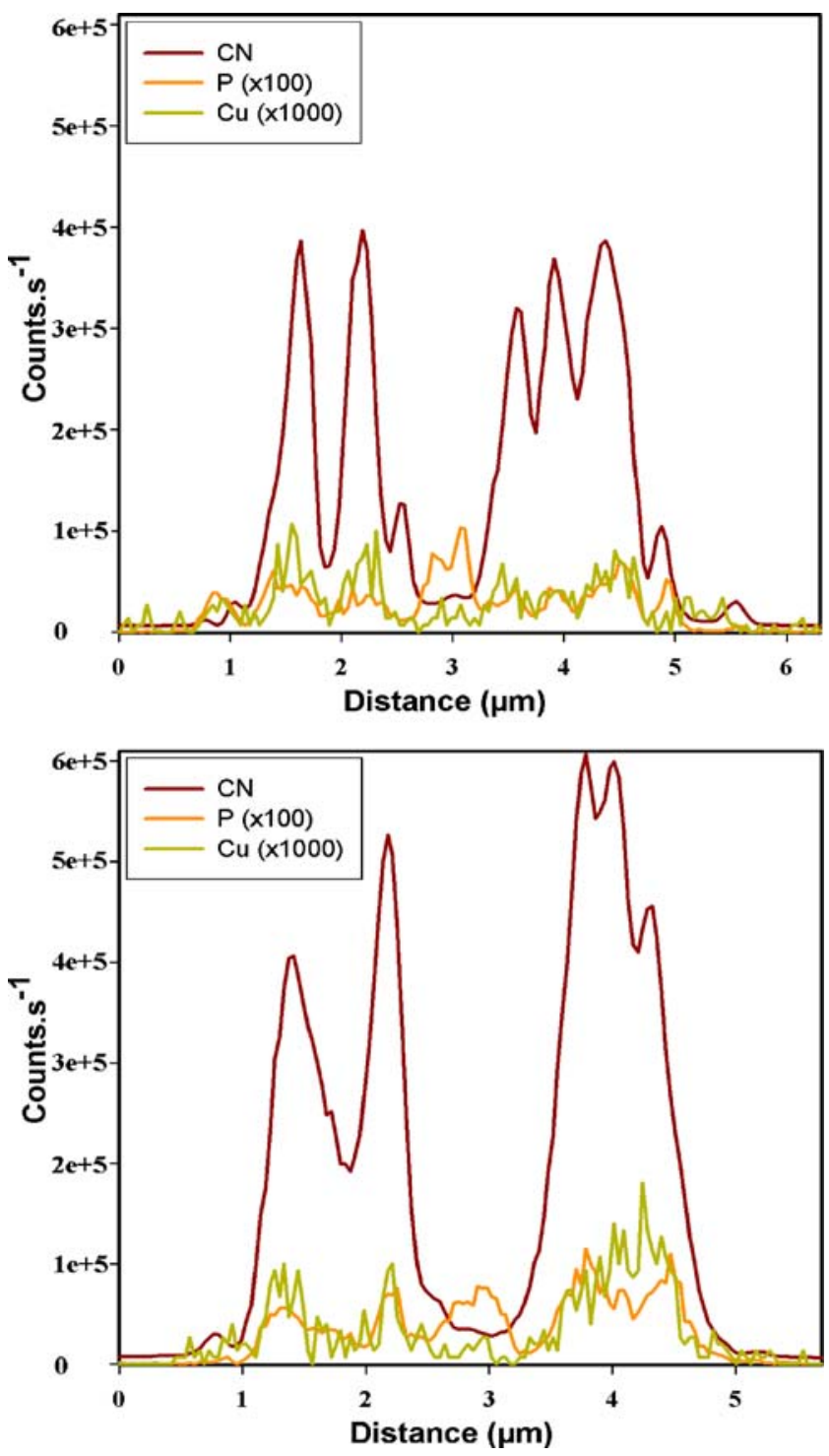

Fig. 4 Line-scan data collected across the alga in the regions of interest 1 and 2, as depicted in Fig. 3

choice to preserve the integrity of tissues and eliminate the risk of ion redistribution [21, 22].

Nonetheless, it is worth mentioning the general consistency of the obtained ${ }^{63} \mathrm{Cu}^{-}$over ${ }^{12} \mathrm{C}^{-},{ }^{12} \mathrm{C}^{14} \mathrm{~N}^{-}$, and ${ }^{31} \mathrm{P}^{-}$ secondary-ion maps with the existing literature on the ultrastructural localization of $\mathrm{Cu}$ in algal cells and the chemical composition of their structural units. For example, $\mathrm{Cu}$ was detected in the starch grains, thecal plates, and osmophilic vesicles of the dinophyceae Prorocentrum micans [23]. Moreover, by use of X-ray energy-dispersion spectroscopy, the presence of trace metals (including $\mathrm{Cu}$ ) was found in polyphosphate bodies of the cyanophyceae Plectonema boryanum [24], bodies that may provide storage sites for essential metals such as $\mathrm{Cu}$.

A large number of $\mathrm{Cu}$ proteins such as plastocyanin and cytochrome oxidase, and $\mathrm{Cu}$ transporting proteins required to supply $\mathrm{Cu}$ for photosynthesis, are found in the thylakoids [25]. Indeed, $\mathrm{Cu}$ was found to accumulate in the thylakoids and pyrenoids of other green algae, for example Oocystis nephrocystioides, by electronic spectroscopic imaging [26].

NanoSIMS can also be a valuable complementary tool, providing information of ecotoxicological value and improving the predictability of the biological effects of toxic metals. Moreover, NanoSIMS can provide further impetus in emerging disciplines such as metallomics and metalloproteomics $[27,28]$ that critically need probes enabling the obtention of spatially resolved trace element maps in a single cell, disciplines that will be increasingly important in the future [29].

\section{Conclusion}

This study demonstrated the applicability of NanoSIMS in imaging $\mathrm{Cu}$ distribution in single micrometer-sized algal cells, simultaneously to major cell constituents' ions. Combined analysis of ${ }^{12} \mathrm{C}^{-},{ }^{12} \mathrm{C}^{14} \mathrm{~N}^{-},{ }^{31} \mathrm{P}^{-}$, and ${ }^{63} \mathrm{Cu}^{-}$ secondary-ion maps provides important information about the sub-cellular distribution of $\mathrm{Cu}$ and possible $\mathrm{Cu}$ interactions with bioactive macromolecules in phytoplankton cells. Correlation of the secondary ${ }^{63} \mathrm{Cu}^{-}$ion map with those obtained for ${ }^{12} \mathrm{C}^{14} \mathrm{~N}^{-}$and ${ }^{31} \mathrm{P}^{-}$demonstrated the possible association $\mathrm{Cu}$ with cell components rich in proteins and phosphorus for cells exposed to both low and high concentrations of $\mathrm{Cu}$.

Acknowledgements Funding for this work by the Swiss National Science Foundation PP002-102640 and the Luxembourgish National Research Fund (Nano programme) are warmly acknowledged. The authors are grateful to Esther Lentzen for NanoSIMS measurements.

\section{References}

1. Suter MJF (2008) Anal Bioanal Chem 390:1957-1958

2. Schwarzenbach RP, Escher BI, Fenner K, Hofstetter TB, Johnson CA, von Gunten U, Wehrli B (2006) Science 313:1072-1077

3. Gaetke LM, Ching KC (2003) Toxicology 189:147-163

4. Olson KJ, Ahmadzadeh H, Arriaga EA (2005) Anal Bioanal Chem 382:906-917

5. Lobinski R, Moulin C, Ortega R (2006) Biochimie 88:1591-1604

6. McDonnell LA, Heeren RMA (2007) Mass Spectrom Rev 26:606-643

7. Lechene CP, Luyten Y, McMahon G, Distel DL (2007) Science 317:1563-1566

8. Lechene CP, Hillion F, McMahon G, Benson D, Kleinfeld AM, Kampf JP, Distel D, Luyten Y, Bonventre J, Hentschel D, Park KM, Ito S, Schwartz M, Benichou G, Slodzian G (2006) J Biol $5: 20.1-20.30$

9. Guerquin-Kern JL, Wu TD, Quintana C, Croisy A (2005) Biochim Biophys Acta 1724:228-238

10. Chandra S, Pumphrey G, Abraham JM, Madsen EL (2008) Appl Surface Sci, Available online 14 May 2008 
11. Stern RA, Fletcher IR, Rasmussen B, McNaughton NJ, Griffin BJ (2005) Int J Mass Spectrom 244:125-134

12. Badro J, Ryerson FJ, Weber PK, Ricolleau A, Fallon SJ, Hutcheon ID (2007) Earth Planetary Sci Lett 262:543-551

13. Hoppe P (2006) Appl Surf Sci (2006) 252:7102-7106

14. Herrmann AM, Ritz K, Nunan N, Clode PL, Pett-Ridge J, Kilburn MR, Murphy DV, O’Donnell AG, Stockdale EA (2007) Soil Biol Biochem 39:1835-1850

15. Audinot JN, Guignard C, Migeon HN, Hoffmann L (2006) Appl Surf Sci 252:6813-6815

16. Krein A, Audinot JN, Migeon HN, Hoffmann L (2007) Environ Sci Poll Res Int 14:3-4

17. OECD (1984) OECD guideline for testing of chemicals. OECD Publications Office, Paris, France

18. Hassler CS, Slaveykova VI, Wilkinson KJ (2004) Limnol Oceanogr Methods 2:237-247

19. Lamelas C, Slaveykova VI (2007) Environ Sci Technol 41:41724178
20. Roemer W, Wu TD, Duchambon P, Amessou M, Carrez D, Johannes L, Guerquin-Kern JL (2006) Appl Surface Sci 252:6925-6930

21. Grovenor CRM, Smart KE, Kilburn MR, Shore B, Dilworth JR, Martin B, Hawes C, Rickaby REM (2006) Appl Surface Sci 252:6917-6925

22. Smart KE, Kilburn MR, Salter CJ, Smith JAC, Grovenor CRM (2007) Int J Mass Spectrom 260:107-114

23. Lage OM, Parente AM, Vasconcelos MTSD, Gomes CAR, Salema R (1996) J Phycol 32:416-423

24. Jensen TE, Baxter M, Rachlin JW, Jani V (1982) Environ Pollut 27:119-127

25. Shikanai T, Müller-Moulé P, Munekage Y, Niyogi KK, Pilon M (2003) Plant Cell 15:1333-1347

26. Soldo D, Hari R, Sigg L, Behra R (2007) Aquat Toxicol 71:307-317

27. Szpunar J (2004) Anal Bioanal Chem 378:54-56

28. Szpunar J (2005) Analyst 130:442-465

29. Koppenaal DW, Hieftje GM (2007) J Anal At Spectrom 22:111-111 